\title{
An Analysis and Research Work on the Chinese Monosyllabic Vocabulary of Indonesian College Students in English Language Education
}

\author{
Dian Lestari ${ }^{1}$, Indah Pujiastuti ${ }^{2}$ \\ \{dianlestari@umrah.ac.id ${ }^{1}$,indah.puji@umrah.ac.id ${ }^{2}$ \}
}

Universitas Maritim Raja Ali Haji, Tanjungpinang, Kepulauan Riau Indonesia, Phone (0771) 4500089; Fax.(0771)4500090 PO.BOX 155

\begin{abstract}
Most Chinese morphemes are monosyllable. When used alone, they are words, and when not used alone, they are word formation components, its mainly due to the lack of morphological changes in Chinese, root compounding is the main method for the generation of new words, and many polysyllabic words are developed from ancient monosyllabic phrases. Most of the Chinese polysyllable words are compound words, but some are double-syllabic simple words, which are mainly manifested as repetitive words and double-syllable words. The disyllabic trend of Chinese vocabulary, namely monosyllabic words which often expanded into two syllables, and multi-syllable words which often compressed into two syllables, there are a large number of four-character idioms in Chinese. In terms of the language structure unit, most of them belong to phrases, and in terms of their sentence-making function, they are equivalent to a word. The vocabulary of any language is always in a state of constant change, and the Chinese vocabulary will continue to develop and change with the development of the material and spiritual civilization of the Chinese society. Furthermore, this research uses a statistical analysis questionnaire survey, while the content is mainly for the learning of Chinese monosyllabic vocabulary of Indonesian college students. It is expected that this research can provide more targeted learning method, hence, it can further improve students' mastery and use of appropriate vocabulary. During the survey and statistics of the vocabulary of a single Chinese learning session in the English Language Education University, it is found that most students will be confused with the Indonesian vocabulary position when they first learn Chinese vocabulary. From the statistics, it can be seen that the error rate of students learning Chinese vocabulary is higher than $84.90 \%$.
\end{abstract}

Keywords: Indonesian university students, monosyllable, Chinese vocabulary, analysis and research 


\section{Introduction}

Based on the long-term observation, experience in teaching Mandarin, as well as the actual situation of Indonesian English Language Education College students in learning Chinese, it is found that college students have an error rate while learning Chinese vocabulary, specifically single Chinese vocabulary. Among them, the single-syllable vocabulary of Chinese has the highest frequency of errors, according to [1], modern Chinese vocabulary has phrases, affixes, and morphemes, and also monosyllable and double syllables. The vast majority of Chinese morphemes are monosyllabic, when used alone, they are words, and when not used alone, they are word formation components, mainly due to the lack of morphological changes in Chinese. Root compounding is the main method of new words generation, many polysyllabic words are developed from ancient monosyllabic words. Most of Chinese polysyllabic words are compound words, but some of them are double-syllable simple words, which are mainly manifested as repetitive words and double-syllable words [2]. The disyllabic trend of Chinese vocabulary, namely monosyllable words which often expanded into two syllables and multisyllable words which often compressed into two syllables, there are a large number of fourcharacter idioms in Chinese [3].

In terms of the language structure unit, most of them belong to phrases, and in terms of their sentence-making function, they are equivalent to a word. The vocabulary of any language is always in a state of constant change, and the Chinese vocabulary will continue to develop and change in line with the development of the material and spiritual civilization of the Chinese society. According to [4], Chinese is not only rich in vocabulary, but also in various methods of vocabulary formation, therefore, it is necessary to really understand the meaning and use of words, and unclear understanding of word structure cannot be condoned. In addition, Chinese words are divided into monosyllabic and double-syllabic words, monosyllabic and polysyllabic words are based on the number of syllables. From this perspective of word formation, there is only a slight difference between "simple words" and "composite words."

\section{Methods}

In order to accurately understand the learning situation of Chinese monosyllabic vocabulary by Indonesian English Language Education College students, the questionnaire method was used in this research. A total of 20 questionnaires is designed and distributed, with the purpose of understanding whether the fourth-grade students made mistakes in learning 
Chinese vocabulary. There are 10 questions in the questionnaire, which refer to students' personal information and the usage of monosyllabic vocabularies. This research uses statistical methods to count the Chinese monosyllabic grammatical error rate of college students.

Table 1. Chinese monosyllable statistics

\begin{tabular}{|c|c|c|c|c|c|c|c|c|c|c|c|c|c|}
\hline \multirow{2}{*}{ NO } & \multirow{2}{*}{ NAME } & \multicolumn{10}{|c|}{ MONOSYLLABLE } & \multirow{2}{*}{$\begin{array}{l}\text { TOTAL } \\
\text { SCORE }\end{array}$} & \multirow{2}{*}{$\begin{array}{l}\text { ERROR } \\
\text { RATE }\end{array}$} \\
\hline & & 就 & オ & 着 & 懂 & 好 & 不 & 对 & 上 & 来 & 去 & & \\
\hline 1 & DENDY JUNDIKA & 0 & 0 & 0 & 0 & 0 & 0 & 0 & 0 & 10 & 0 & 10 & 90 \\
\hline 2 & $\begin{array}{c}\text { REISKA } \\
\text { KRISTIEN } \\
\text { SIMANUNGKALIT }\end{array}$ & 0 & 0 & 0 & 0 & 10 & 0 & 10 & 10 & 0 & 10 & 40 & 60 \\
\hline 3 & NURUL AZILA & 10 & 10 & 0 & 0 & 10 & 0 & 10 & 0 & 0 & 10 & 50 & 50 \\
\hline 4 & MARIANAWATI & 0 & 0 & 0 & 10 & 0 & 0 & 0 & 0 & 10 & 0 & 20 & 80 \\
\hline 5 & NITAMARA & 0 & 10 & 0 & 0 & 0 & 0 & 10 & 0 & 0 & 0 & 20 & 80 \\
\hline 6 & $\begin{array}{c}\text { SELIA } \\
\text { WULANDARI }\end{array}$ & 0 & 10 & 0 & 0 & 0 & 0 & 10 & 0 & 0 & 10 & 30 & 70 \\
\hline 7 & $\begin{array}{c}\text { INDRA } \\
\text { KURNIAWAN }\end{array}$ & 0 & 0 & 10 & 0 & 0 & 0 & 0 & 10 & 0 & 0 & 20 & 80 \\
\hline 8 & $\begin{array}{c}\text { ADELIA } \\
\text { GUSTARINA }\end{array}$ & 10 & 0 & 0 & 0 & 10 & 0 & 0 & 10 & 0 & 0 & 30 & 70 \\
\hline 9 & MITA NOFYANA & 0 & 10 & 0 & 0 & 10 & 0 & 0 & 0 & 10 & 0 & 30 & 70 \\
\hline 10 & $\begin{array}{l}\text { BELLA } \\
\text { FINALISTY }\end{array}$ & 0 & 0 & 0 & 10 & 0 & 0 & 0 & 0 & 0 & 0 & 10 & 90 \\
\hline 11 & $\begin{array}{l}\text { SYARAH DWI } \\
\text { ANGGRAINI }\end{array}$ & 10 & 0 & 0 & 10 & 10 & 0 & 0 & 0 & 0 & 10 & 40 & 60 \\
\hline 12 & $\begin{array}{l}\text { REGIESTA } \\
\text { ARDILA }\end{array}$ & 0 & 0 & 0 & 10 & 0 & 0 & 0 & 10 & 0 & 0 & 20 & 80 \\
\hline 13 & YOLI ANDINI & 0 & 0 & 0 & 10 & 0 & 0 & 0 & 0 & 0 & 0 & 10 & 90 \\
\hline 14 & $\begin{array}{c}\text { TENGKU RAHMA } \\
\text { TRISYA }\end{array}$ & 10 & 0 & 0 & 0 & 0 & 0 & 10 & 0 & 0 & 10 & 30 & 70 \\
\hline
\end{tabular}




\begin{tabular}{|c|c|c|c|c|c|c|c|c|c|c|c|c|c|}
\hline 15 & $\begin{array}{l}\text { GABRIELLA } \\
\text { THERESIA } \\
\text { HUTABARAT }\end{array}$ & 0 & 0 & 0 & 10 & 0 & 0 & 0 & 0 & 0 & 0 & 10 & 90 \\
\hline 16 & MILO SAPUTRA & 10 & 0 & 0 & 10 & 0 & 0 & 10 & 0 & 0 & 10 & 40 & 60 \\
\hline 17 & SUPI ANDANI & 0 & 0 & 10 & 0 & 0 & 10 & 0 & 0 & 0 & 0 & 20 & 80 \\
\hline 18 & $\begin{array}{l}\text { FIORIAN GISTI } \\
\text { SEPTIANA }\end{array}$ & 0 & 0 & 0 & 10 & 0 & 10 & 0 & 0 & 0 & 10 & 30 & 70 \\
\hline 19 & $\begin{array}{l}\text { ZETHRO GENIK } \\
\text { DEWANGGA }\end{array}$ & 0 & 0 & 0 & 0 & 0 & 10 & 0 & 0 & 0 & 10 & 20 & 80 \\
\hline 20 & YENI KARTIKA & 0 & 0 & 0 & 0 & 0 & 10 & 0 & 0 & 0 & 0 & 10 & 90 \\
\hline \multicolumn{12}{|c|}{ SUMMARY ERROR RATE } & 100 & $84.90 \%$ \\
\hline
\end{tabular}

\section{Research Results and Analysis}

Through investigation and analysis conducted, this research discovered the reasons and problems of the fourth grade students in learning Chinese vocabulary are relatively large. Most of the students in choosing the correct grammatical position are interfered by their mother tongue to make wrong judgments, specifically when they use the word "着", the time error rate is extremely high. From the statistical data, it seems that $84.90 \%$ of the answers are quite high for the students to choose incorrect vocabulary. To enable students to choose the right position while choosing vocabulary, they must first master the subject-predicate-object structure of Chinese grammar, the collocation of Chinese vocabulary single-syllable words, and the differences between phrase and vocabulary. The vocabulary in Indonesian can be used alone, but it does have a big difference in usage from the Chinese Vocabulary, it can be seen that there will be a higher frequency of grammatical errors in the selection of subject and predicate. In addition, Chinese words can be divided into three categories in terms of structure, namely simple words, compound words and abbreviated words. Simple words are composed of one morpheme, and in terms of pronunciation, there are more than one single syllable, such as "Just"; "cai" and "lai", "Go"; "Zhu", "Good" and "Yes", "Shang" [5], [6], [7]. According to the practical situation of Chinese monosyllabic words, it can be explained that Indonesian students make mistakes in using simple words. In sentences, other words are often used to express the meaning of 
monosyllabic words. In addition to misusing monosyllabic words, Indonesian students often mistakenly add other words.

\section{Conclusion}

Through the survey and statistics of the vocabulary of a single Chinese learning session in the English Language Education University, this research found that most students will be confused with the Indonesian vocabulary position when they first learn Chinese vocabulary. From this statistics, it can be seen that the error rate of students learning Chinese vocabulary is higher than $84.90 \%$. In order to avoid making mistakes for students who learn Chinese vocabulary, specifically while choosing a single vocabulary, they must first master the subject, predicate and object of Chinese grammar. In line with this, teachers can use different teaching methods to improve students' understanding of vocabulary, and also use word collocation to mixed teaching. In addition, it is expected that it can be used as a reference for improving students' Chinese vocabulary learning in the future.

\section{References}

[1] Cao Wei, A. (2004): Modern Chinese Vocabulary. Pp. 54-67 Peking University Press.

[2] Peng Xiao Chuan, Li Xiao Ji, Wang Hong A. (2012): Explanation of 201 Cases of Grammar in Teaching Chinese as a Foreign Language. The Commercial Press.

[3] Huang Bo Rong, Liao Xu Dong, A. (2007): Modern Chinese. Higher Education Press, the Commercial Press.

[4] Zhou Zu Mou , A. (2006): Chinese Vocabulary Speech. pp. 17-24. Foreign Language Teaching and Research Press.

[5] Liu Yue Hua, Pan Wen Yu, Gu Hua A. (2009): Practical Modern Chinese Grammar. The Commercial Press.

[6] Wang Cesan, A. (2005): Teaching Theory Draft. People's Education Press.

[7] Zhang Bin, A. (2002): Modern Chinese Teaching Reference and Training. pp. 13-18. Fudan University Press. 